Article

\title{
Biogas Potential of Wastes and By-Products of the Alcoholic Beverage Production Industries in the Spanish Region of Cantabria
}

\author{
Jesús A. Montes * $*$ and Carlos Rico \\ Department of Water and Environmental Science and Technologies, University of Cantabria, Avda. Los Castros, \\ s/n, Santander39005, Spain; carlos.rico@unican.es \\ * Correspondence: jesus-andres.montes@alumnos.unican.es; Tel.: +34-942-201-848; Fax: +34-942-201-703
}

Received: 5 October 2020; Accepted: 21 October 2020; Published: 24 October 2020

Featured Application: This paper studies the production and amount of by-products of an emerging industry in a small region of Spain, dealing with their possible treatment and valorization through anaerobic digestion. Thus, some guidelines could be taken from it and applied in similar cases in other regions where alcoholic beverage production is an important economic resource.

\begin{abstract}
The industry of alcoholic beverage production has been, historically, both an important economic engine and a source of wastes and pollution (due to the production processes by themselves and to the energy requirements) in a number of countries. In the small region of Cantabria, in northern Spain, the production of alcoholic beverages as an economic sector has been growing in importance in recent years. Thus, there is a new flow of waste for which specific management plans have yet to be developed. The result is an increase in the total amount of urban waste to be disposed. Anaerobic digestion can be a suitable in-situ solution for the treatment of the generated wastes providing a source of renewable energy which can be a supply for the processes in these industries, reducing the emission of greenhouse gases associated to the use of fossil fuels, all of this benefitting both environment and economy. In this work the authors present the information gathered about waste generation and the biomethanogenic potential of the most important wastes generated in the industries. As a result, specific strategies could be designed for the industrial sector in the region, of which other small agro-industries can benefit.
\end{abstract}

Keywords: biochemical methane potential (BMP); methanogenesis; anaerobic digestion; waste valorization; food and drink industry; bioeconomy

\section{Introduction}

\subsection{Generalities}

Cantabria is a small region in the north of Spain. Agri-food industry in Cantabria is an important economy sector both in terms of economic relevance and of social interest, with sales around $€ 1 \mathrm{~B}$ (1000 million $€$ ) which amounts $6 \%$ of the GDP of the region and provides $10 \%$ of the jobs [1].

The total production of waste in 2014 in Spain and in the industrial subsector of food, drinks and tobacco was of 2595.5 thousand tons, being the most of it (2586.2 thousand tons) non-hazardous wastes. This sub-sector is the fifth in total amount of waste production [2]. Environmental and economical rationality suggest following the circular economy principles making the generated wastes useful as raw materials for other processes. They could be used eitherin the same industrial sector or in other sectors, associated or not, pre-existent or newly created. In that sense it would be necessary to count 
on robust tools to differentiate between wastes and co-products or by-products as in Springer and Schmitt [3], using the rectangular choice-of-technologies model. Life cycle assessment (LCA) and other techniques [4] are useful instruments to focus on the creation of different by-products throughout the production processes and helps to develop strategies for reuse, recycling or treatment [5].

As shown by research and experience, it is a fact the by-products of the industry can produce the raw material for a series of final products of higher added value [6-8] fulfilling the principles of circular economy. However it is necessary to exert caution due to the fact that, in some cases, though the processes could be feasible, the environmental cost of the valorization of some by-products can be very high, making the process economical and environmentally unviable [9].

In Cantabria, the total amount of vegetable waste originating from agri-food industries which includes those of alcoholic beverage production and distillation amounted to 799 thousand tons in 2010 [1] (the last year for which we have statistics). All this waste was qualified as non-hazardous materials, making it susceptible of being subject of biological treatment for their management and possible valorization [10]. In this sense anaerobic treatment could be a valid option as, not only it is a proven and reliable waste management and treatment option but also a source of energy in the shape of biogas, which can be an interesting option to fulfil the energetic needs of the industry while, at the same time, reducing the need of fossil fuels and the emissions of greenhouse gases.

In recent times, the Cantabrian industry of alcoholic beverage production has undergone remarkable changes, both in terms of an increase in production and varieties of available products as the importance of the sector in the productive framework of the region, with a growing number of new companies working in this field.

\subsection{Historical and Current Situation}

Historically, the beverages produced which had the biggest importance in produced volume were wine and cider, with the implantation of beer breweries at the beginning of the 19th century with most of their production being export product. However, and with the phylloxera (Dactylosphaera vitifoliae) infestation that arrived in the region at the beginning of the 20th century, most vine cultivation and wine production was resumed until recent times [11]. Cider production disappeared as a result of drinking trends, as its consumption was substituted for that of wines imported from other Spanish regions [12]. And all beer breweries ended up closing as the exportation to Latin American countries of food and beverages suffered a sharp decrease through the second half of the 19th century and the beginning of the 20th [13].

Among the traditional beverages produced in Cantabria, only the "orujo de Potes" remained as a significant production. "Orujo" is a grape marc spirit (as defined by the Regulation(EC) No 110/2008 of the European Parliament and of the Council of 15 January 2008 [14]) which originally was made through the fermentation and distillation of winemaking by-products as well as of low-quality wines in the region of Liébana within Cantabria, where the last vineyards were maintained in the region. This spirituous drink has seen an increase both in terms of quality and of the production amount, becoming a flagship of the regional gastronomy. Since September 23rd of 2010 and under the nomination "CC Calidad Controlada" (controlled quality) [15], orujo has to be made exclusively by distillation of grape marc of locally produced grapes. This, in turn, has caused an increase in grape production and the reestablishment of wine production in the zone as a way to make the most of grape musts, which ironically had become by-products of the spirit production, reversing the historical roles of product and by-product.

While the market demand for orujo has remained stable or slightly increased along the years, the distillers and producers have widened the range of products in order to increase their sales and presence in the market. Thus, several alcoholic beverages are produced, being distilled orujo the main ingredient for all of them. A number of liqueurs and crèmes (as defined by the Regulation(EC) No 110/2008 of the European Parliament and of the Council of 15 January 2008 [14]) are produced using orujo as the distillate of agricultural origin providing the alcoholic content of the beverage. The sales of 
these liquors and crèmes more than quadruplicate those of orujo per se, increasing the production of the original beverage and the demand of grape marc in order to produce them.

On the other hand and after the decrease in viability of small dairy cattle farms and subsequently the lack of use and/or abandonment of a number of hectares of arable land used until then as meadows for dairy cattle feeding, has brought an interest in new ways of making the land profitable and so wine production in other parts of the region is knowing a renewed interest. New cultivars and varieties of grapevines are being used, as well as different production and agricultural techniques. There has also been a resurgence in cider production, due to ethno-cultural reasons.

In recent times, a number of small artisan beer breweries have appeared throughout the region with varied rates of success. Nevertheless, some of them have reached a respectable consumption rate, with a growth in production and an expanding distribution network.

Finally, the appearance of some new distilleries in non-traditional zones which manufacture spirits other than the traditional ones (mainly gins and dry gins) which have had a good acceptance, has triggered a change in the spirit production philosophy, with more and more of the traditional distillers of orujo and grape marc spirits widening their range of products and so creating new business opportunities for the companies.

As could be expected, this rising trend (in range and production amount in general) in alcoholic beverage production, has brought an increase in wastes and by-products from such a dynamic industrial sector [16]. Most of these waste sources work as micro-floods of potentially highly polluting products, which have no specific treatment due to their small size. Solids are usually incorporated into the usual chain of treatment of urban wastes or used as feedstock for farm animals, while liquids normally enter the net of urban and industrial wastewater treatment.

The aforementioned wastes and by-products have a number of common characteristics: a high COD (chemical oxygen demand) and biodegradability and an acidic $\mathrm{pH}$. They are well suited for anaerobic treatment, provided that, in some cases, certain conditioning might be performed $[17,18]$. In an industry in which there is always a usage of energy, mainly in the shape of heat, the biogas generated in anaerobic treatments could be a welcome asset, beneficial not only from an environmental point of view but also as a help for the economics of the factory by itself.

The by-products generated can be solids or liquids, of which we may cite:

- Among solids, grape marc, raw or fermented and distilled from wine and orujo production, as well as apple pomace from cider manufacturing; brewers and distillers spent grains in beer breweries and from ethyl alcohol of agricultural origin production (the basis for a number of spirits); and botanics and aromatics for some distilled beverages.

- Among liquids, trub from breweries; pot ales and washes from distillation; and wash and process waters.

Under the point of view of the treatment and possible utilization of these by-products through anaerobic treatment, a characterization of them is necessary in order to know their potential methane yield, as well as possible particular characteristics which could pose as setbacks in case industrials systems are implemented [19-21]. While for some of them (winery wastes) there is a wide knowledge of the field, for some others (as exhausted grape marc or distilled gin wash) there is no literature available. As each industry works in a framework of scale economies, these data are crucial to assess the feasibility of the processes and allows knowing the minimum amount of wastes which could make the investment on the system a profitable one. Also, there's a lack of quantification of the waste flow, both at the present time and in a future horizon of production.

This article deals with a number of wastes and by-products from different beverage production industries using BMP (biochemical methane potential) tests on each one, so these questions could be answered [22-25]. 


\section{Materials and Methods}

\subsection{Substrates}

A number of substrates were chosen as representative of the most significant part of the wastes produced in the alcoholic beverage production in Cantabria. Spent brewer's grains were collected at the facilities of Cervezas Artesanales de Cantabria S.L. (which operates under the brand "Dougall's") sited in the municipality of Liérganes. Grape marcs, both unused for distillation (which could be representative of wine production) and exhausted (after distillation for the production of orujo) were collected at the distillery of Orujo de Liébana S.A. (also known by the company acronym Orulisa) in Tama. The wastes from dry gin production, both solid and liquid, were obtained from the distillery of Destilería Siderit S.L. in Puente Arce. Finally, as this latter distillery is immersed in a process for the production of whisky in the region, with the University of Cantabria working under an agreement for its production and development, the pot ale generated in the research and assays carried out in the university laboratories was also tested. The characteristics of these substrates are shown in Table 1.

Table 1. Characteristics of wastes and by-products analyzed in the study (TS and VS are expressed as a percentage of the total mass).

\begin{tabular}{ccccc}
\hline Wastes and By-Products & TS (\%) & VS (\%) & TKN (g/kg TS) & P (g/kg TS) \\
\hline Pot ale & 6.06 & 5.55 & - & - \\
Trub & 9.51 & 8.69 & - & - \\
Gin spent wash & 8.32 & 7.68 & 1.44 & 0.36 \\
Gin spent botanics & 35.6 & 34.3 & 1.56 & 0.17 \\
Brewers' spent grains & 25.2 & 24.2 & 3.59 & 0.56 \\
Grape marc & 44.1 & 38.3 & 2.21 & 0.22 \\
Exhausted grape marc & 31.9 & 29.1 & 2.43 & 0.24 \\
\hline
\end{tabular}

\subsection{Inoculum and Conductive Material}

The inoculum used consisted in the anaerobic effluent from a lab-scale digester treating liquid dairy manure and food waste (manure inoculum-MI). Characteristics of the inoculum are shown in Table 2.

Table 2. Characteristics of the inoculum used in the study (TS and vs. are expressed as a percentage of the total mass).

\begin{tabular}{cc}
\hline & Inoculum \\
\hline $\mathrm{TS}(\%)$ & 2.23 \\
$\mathrm{VS}(\%)$ & 1.16 \\
$\mathrm{COD}\left(\mathrm{g} \mathrm{L}^{-1}\right)$ & - \\
$\mathrm{pH}$ & 7.9 \\
Alkalinity $\left(\mathrm{g} \mathrm{CaCO}_{3} \mathrm{~L}^{-1}\right)$ & 12.1 \\
TAN $\left(\mathrm{g} \mathrm{NH}_{4}^{+}-\mathrm{N} \mathrm{L}^{-1}\right)$ & 2.7 \\
\hline
\end{tabular}

Powdered Activated Charcoal (PAC, 75-150 $\mu \mathrm{m}$ ) was used as conductive material in a number of experiments. The use of a conductive material in addition to the inoculums has proven to be a significant factor maximizing the biomethanogenic performance of the processes for some substrates [26].

\subsection{Experimental Set-up: Batch Experiments}

All batch experiments were conducted in triplicate in anaerobic $250 \mathrm{~mL}$ serum bottles capped with rubber septum sleeve stoppers. Bottles were filled with the amount of substrate containing $0.5 \mathrm{~g}$ vs. and the amount of inoculum to provide an inoculum to substrate ratio of 2 (based on volatile solids). Blanks were also tested with and without PAC. After filling the bottles, nitrogen was flushed to remove 
the oxygen in the headspace. Afterwards, the bottles were capped and placed in an incubator at $38^{\circ} \mathrm{C}$. All the reactors were manually stirred once a day. The test was stopped for each substrate when methane production was negligible in all the samples. Results are expressed as means subtracting methane production from the blanks. Once the experiment was stopped, the reactors were opened to measure the $\mathrm{pH}$, redox potential and VFAs (volatile fatty acids) in the effluents.

\subsection{Analytical Techniques}

The biogas and methane production were measured by the manometric method as described in Valero et al. [27]. Headspace pressure was measured in the headspace of the reactors through the septum with a syringe connected to a digital pressure transducer with silicon measuring cell (ifm, Germany-type PN78, up to 2000 mbar). The biogas samples were taken through the septum by a needle connected to a syringe and analyzed on a $2 \mathrm{~m}$ Poropak T column in a HP 6890 gas chromatograph (GC) system with helium as the carrier gas and a TCD (thermal conductivity detector). The methane volumes are expressed at $0{ }^{\circ} \mathrm{C}$ and $1 \mathrm{~atm}$ in dry conditions. VFA were determined using a HP $6890 \mathrm{GC}$ fitted with a $2 \mathrm{~m}$ 1/8-in glass column, liquid phase 10\% AT 1000, packed with solid-support Chromosorb W-AW 80/100 mesh. Nitrogen was used as the carrier gas at a flow rate of $14 \mathrm{~mL} / \mathrm{min}$ and a FID (flame ionization detector) was installed. Total Solids (TS), Volatile Solids (VS), chemical oxygen demand (COD), total ammonia nitrogen (TAN) and bicarbonate alkalinity were analyzed according to Standard Methods (APHA, 1998).

\section{Results}

The results of the BMP tests show that the liquid substrates analyzed show a significantly higher methane yield per kilogram of volatile solids than the solid ones. This fact is representative of the biodegradability of the substances in these substrates and of their availability for the methanogenic microorganisms. However and due to the low concentration of TS in the liquid by-products, the final yields of biogas per kilogram of total sample were higher in solid substrates except for exhausted grape marc. The specific methane productions of the different substrates obtained in the BMP tests are shown in Figure 1, expressed as $\mathrm{L}_{\mathrm{N}} \mathrm{CH}_{4} \mathrm{~kg}^{-1} \mathrm{VS}$ and in Figure 2 as $\mathrm{L}_{\mathrm{N}} \mathrm{CH}_{4} \mathrm{~kg}^{-1}$ fresh sample.

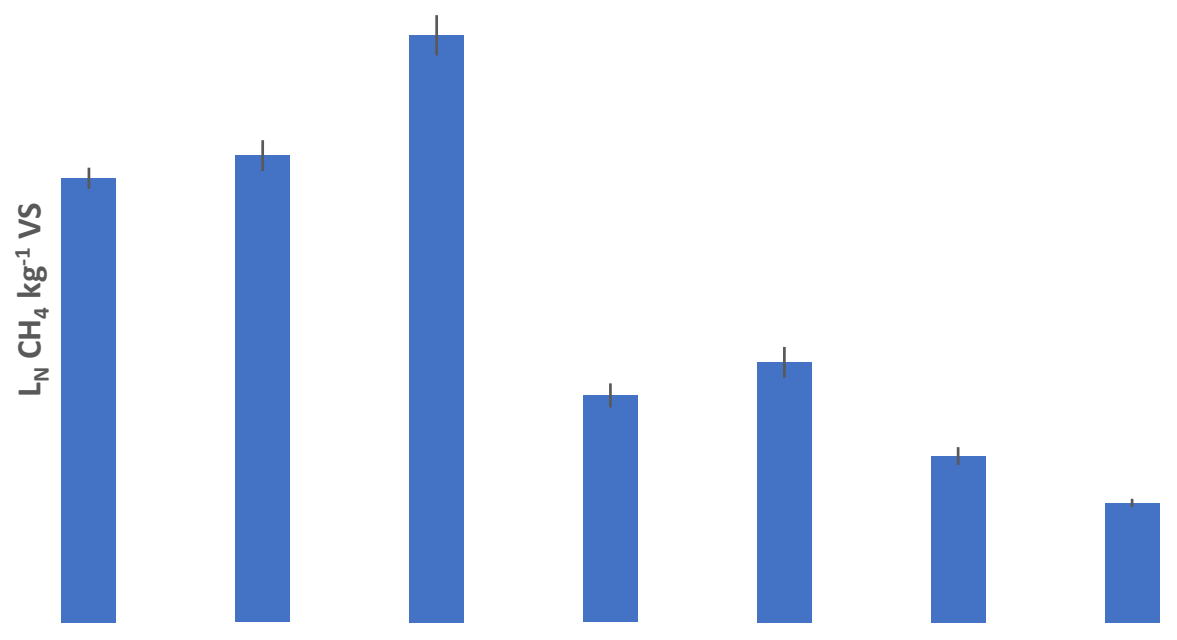

Figure 1. Total specific methane production of by-products from the alcoholic beverage production in $\mathrm{L}_{\mathrm{N}} \mathrm{CH}_{4} \mathrm{~kg}^{-1}$ vs. from the BMP tests (SD for each substrate: PA, 13; T, 19; GSW, 25; GSB, 15; BSG, 19; GM, 11; EGM, 5). 


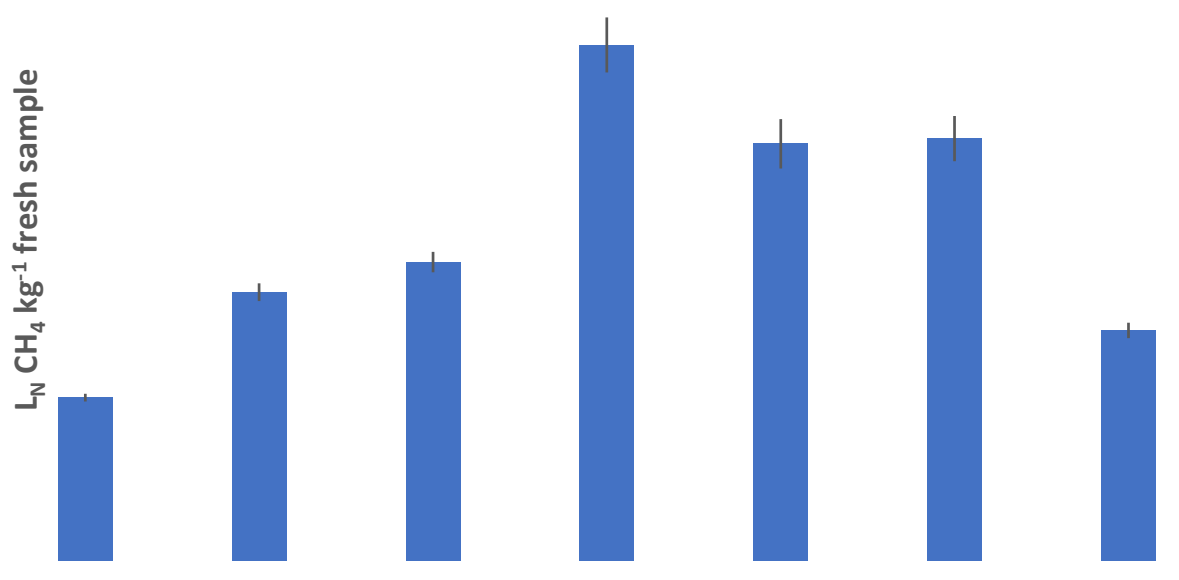

Figure 2. Total specific methane production of by-products from the alcoholic beverage production in $\mathrm{L}_{\mathrm{N}} \mathrm{CH}_{4} \mathrm{~kg}^{-1}$ fresh sample from the BMP tests (SD for each substrate: PA, 0.7; T, 1.7; GSW, 1.9; GSB, 5.1; BSG, 4.6; GM, 4.2; EGM, 1.5).

About the solids, the one which showed the biggest methane yield per kilogram of volatile solids were the spent brewer's grains followed by the solid waste from gin production. Grape marc also showed good behavior though inferior to the previous substrates, due to the high content of lignin (which cannot be digested in anaerobic treatment) of this type of waste [28]. Exhausted grape marc was the less productive substrate in terms of biogas production. This could be expected since most sugars and other compounds found in the marc previous to fermentation and distillation, have been transformed into ethanol and other compounds and extracted in the spirit making process.

Pot ale, while being a substrate created in large amounts in spirit making, has not been the subject of extensive research. Barrena et al. [29] reported a value of $554 \mathrm{~L} \mathrm{CH}_{4} \mathrm{~kg}^{-1}$ vs. for pot ale in batch tests, which fits very well with the attained results in this work of $542 \mathrm{~L} \mathrm{CH}_{4} \mathrm{~kg}^{-1} \mathrm{VS}$.

The attained values for brewer's spent grains of $322 \mathrm{~L} \mathrm{CH}_{4} \mathrm{~kg}^{-1} \mathrm{VS}$, are placed in the fork between those reported in Vitanza et al. [30] of $429 \mathrm{~L} \mathrm{CH}_{4} \mathrm{~kg}^{-1}$ vs. and similar to those in Bochmann et al. [31] of $409.8 \mathrm{~L} \mathrm{CH}_{4} \mathrm{~kg}^{-1}$ vs. and Oliveira et al. [32] with $301 \pm 5 \mathrm{~L} \mathrm{CH}_{4} \mathrm{~kg}^{-1}$ VS. The latter gives, as well, a value for trub and used yeast of $515 \pm 4 \mathrm{~L} \mathrm{CH}_{4} \mathrm{~kg}^{-1} \mathrm{VS}$, inferior to the $578 \mathrm{~L} \mathrm{CH}_{4} \mathrm{~kg}^{-1}$ vs. attained in the present study.

About grape marc, the relatively modest values of $206 \mathrm{~L}_{\mathrm{N}} \mathrm{CH}_{4} \mathrm{~kg} \mathrm{VS}^{-1}$ attained in the tests are quite superior to those reported in Dinuccio et al. [33] of $116 \mathrm{~L}_{\mathrm{N}} \mathrm{CH}_{4} \mathrm{~kg} \mathrm{VS}^{-1}$ and similar to those in Hungría et al. [34], reporting figures of $252 \pm 35 \mathrm{~L}_{\mathrm{N}} \mathrm{CH}_{4} \mathrm{~kg} \mathrm{VS}^{-1}$ but are inferior to those found in Fabbri et al. [35] of $273.08 \mathrm{~L}_{\mathrm{N}} \mathrm{CH}_{4} \mathrm{~kg} \mathrm{VS}^{-1}$ for grape marc used in white wine production or the ones attained by Da Ros et al. [36] of 347-360 $\mathrm{L}_{\mathrm{N}} \mathrm{CH}_{4} \mathrm{~kg} \mathrm{VS}^{-1}$. This may be related to the varietal characteristics of the grapes grown in the region and their own cultivation characteristics associated with a regional climate in which the production of sugars in the fruit at the time of ripening tends to reach low maximization levels.

No values have been found in the available literature for the biomethanogenic potential of exhausted grape marc or for spent wash and solid spent botanicals and aromatics from gin production (aside from other works from the authors [37], where $699.54 \mathrm{~L}_{\mathrm{N}} \mathrm{CH}_{4} \mathrm{~kg} \mathrm{VS}^{-1}$ were obtained for gin spent wash). So the values of 148,727 and $281 \mathrm{~L}_{\mathrm{N}} \mathrm{CH}_{4} \mathrm{~kg} \mathrm{VS}^{-1}$ obtained cannot be compared with any results from previous studies from other authors.

\section{Discussion}

\subsection{Wastes and By-Products: Generation and Characteristics}

The usage of wastes and by-products of the different industrial premises of alcoholic beverage production for biogas production should be assessed by multi-criteria analysis. Feiz and Ammenberg [38,39] 
propose a complete methodology for this analysis, though the total number of parameters used by them are not available for this study given its limitations; nevertheless and based in the set of parameters obtained and applicable to the methodology, the feasibility of the process is proven. Also, Vlachokostas et al. [40] have developed a decision support system providing more managerial insights for the establishing and implementing of units of alternative biowaste treatment, showing the benefits and promotion of local bioeconomies.

An important factor in waste management is the spatial distribution of the waste sources and their mode of production. This may be a clustered one with production points with concentrated productions of waste with a high pollutant potential; or a scattered one with diffuse productions of waste over extended areas. In Figure 3, we can see the spatial distribution of a number of production centers of alcoholic beverages (and thus, of the wastes associated to the specific production) throughout the region. It could be noticed that there is a trend of these centers to be gathered, in a certain proximity. This may be an advantage for join waste management when the production of waste or by-products from individual companies show low critical mass levels; in these cases the individual investment for the company for such installations and premises needed for their treatment could be profitable. Even though there is a good potential for a conjoined treatment of these wastes, they will be treated individually in this work to determine their specific characteristics and potential as substrates to undergo anaerobic treatment and their specific potential biomethanogenic production.

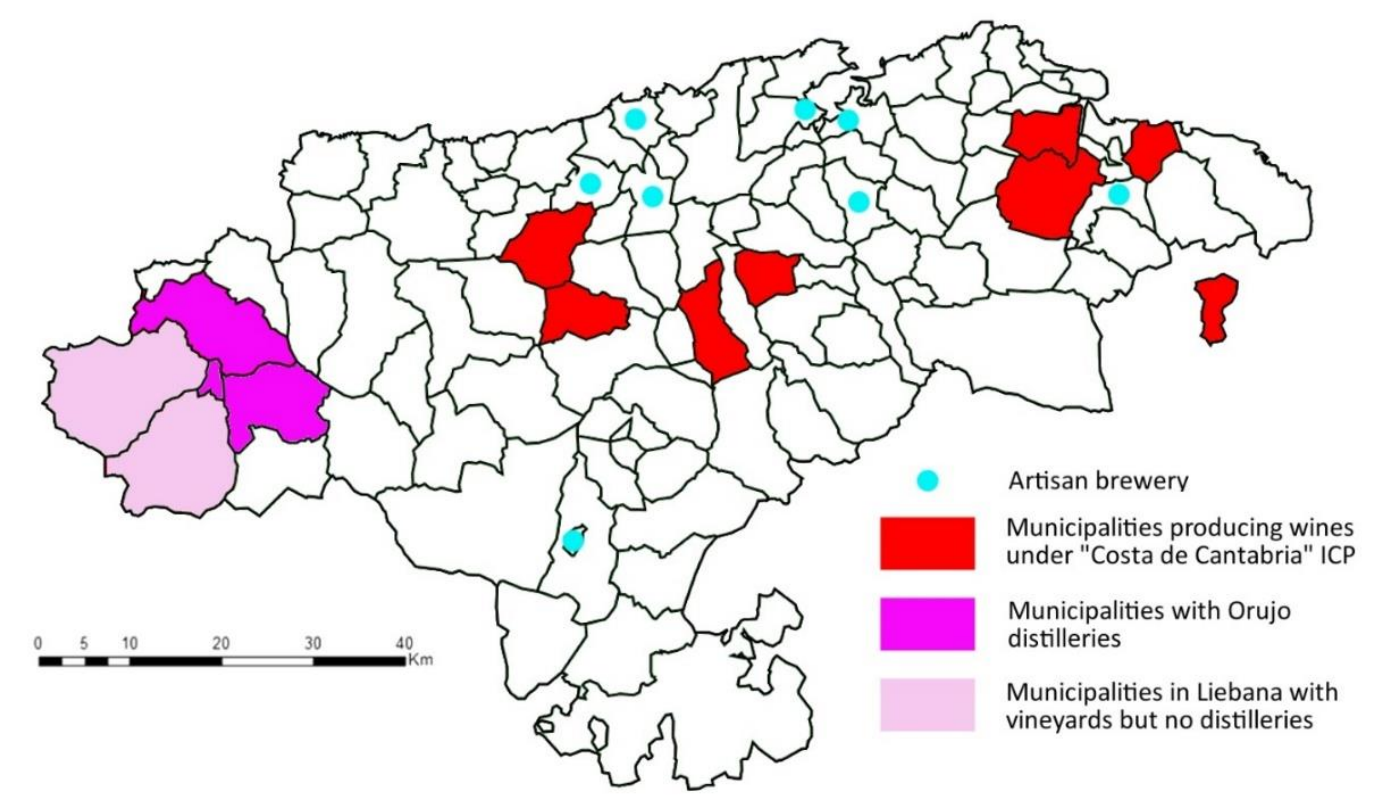

Figure 3. Location of the main by-product associated to the alcoholic beverage production generation areas in the region of Cantabria (Spain). Breweries and municipalities with vineyards and orujo distilleries.

Grape marc has, for a long time, been subject to research, both as a waste and as a potential source of energy. Both the marc "as is," as a by-product of wine production and the "exhausted one" after fermentation and distillation as a by-product of grape marc spirit making, have the characteristic of being seasonal products, as both wine and marc spirit are items made at a certain time of the year. Wine grape marc appears shortly after grape harvest and their crushing to obtain grape musts and the only treatment it might receive is just a drying, usually under the sun in natural conditions. Then it might be pressed and, either be used to produce grape marc spirit, as livestock feed or simply be dumped at a garbage disposal facility. In Cantabria, exhausted grape marc used to produce orujo is simply disposed of.

Grape marc as a potential source of biogas has been subject of research [41], attaining values of up to $28 \mathrm{Nm}^{3} \mathrm{t}^{-1}$. It produces a high yield of biogas on the first days (as could be expected by the high 
presence of sugars in the dry matter) which later decreases as sugars become depleted and the main source of biogas is the fibrous matter in grape waste. Throughout this period, biogas production rate becomes quite stable until eventually the total depletion of food resources for the microorganisms responsible of the process arrives. It has also been found that the presence of grape seeds is beneficial for the process.

There have been a number of studies about the quantities and characterization of winery wastes and by-products [42] as well as the economic significance of their valorization against the cost of not doing it [43], both under the viewpoint of the extraction of compounds in grape wastes and as micro-scale energy valorization of the remains [35].

The process of making orujo, basically consists on: firstly, the dried grape marc is soaked and moistened, after which the mix of marc and water is fermented by the yeasts which appear naturally in the marc; after fermentation, the whole mix is distilled in still pots. After distillation, the remains in the still pot are just discharged, loaded in containers and disposed of.

According to official data of the ODECA in 2019 (the official organism that certifies the production of food and beverages in Cantabria, working as a regulation council) [44], the production of orujo that can be set under the official denomination of "orujo de Liébana" in 2013 was of around 20,300 L. To this amount can be added the $5337 \mathrm{~L}$ commercialized as orujo without official denomination and to the distillation products from the distilleries used to produce other alcoholic beverages (based in orujo), like liqueurs and crèmes. Taking in account data gathered in a visit to a well-established distillery and extrapolated to the regional production, a liter of orujo requires more than $6 \mathrm{~kg}$ of dry grape marc which turn into $10 \mathrm{~kg}$ of hydrated exhausted grape marc after distillation. This gives us a total number of $126,450 \mathrm{~kg}$ of grape marc used for production which become $154,269 \mathrm{~kg}$ of solid waste.

The production has two distinct features: seasonality (the whole of the distillations take place in around 3-4 weeks in October-November) and geographic restriction (the Liébana region spreads over 570 square kilometers and encompasses seven municipalities, where grape production is restricted to the less mountainous areas). Waste management is performed by an authorized waste manager, who provides the containers for the storage (of 9 cubic meters and able to contain up to 15 tons), transport and disposal of the used marc.

About beer brewery wastes, they have been subject to extensive research due to a number of facts: They are usually produced in large amounts and they have high pollution potential. In fact, since centuries ago, breweries have been detected as pollution sources, therefore being among the first industries that applied systems to reduce or recycle waste and treat liquid emissions. Some treatment alternatives used historically for the solid or semi-solid wastes, such as spent brewer's grains (SBG) and used yeasts, have been using them as livestock food or, in the case of spent yeast (trub), as human food after some lysis processes of yeast cells (Marmite). Other not-so-easily treatable wastes are brewery slurries, composed of materials used to filter beers (kieselguhr of diatomaceous earth) and the remains of filtration. Brewery wastewaters have traditionally undergone conventional aerobic sewage treatment, though they have proven to be an ideal subject for anaerobic treatment due to their characteristics.

In recent times and due to the increasing costs of energy, solid or semi-solid brewery wastes have been subject of research as a potential source of biofuels that might be used to reduce the costs associated to energy consumption (mainly in the shape of heat) in the brewing processes [45]. Anaerobic treatment of wastes with the production of biogas provides a source of energy as well as a way of treatment for wastes and by-products which fits particularly well in brewery production [46], as biogas is storable and can be used for discrete processes requiring energy, like the boiling of worts or the pasteurization of bottled beer for example. A number of solid wastes (like brewers' spent grains, BSG's) pose no further issues for their use and treatment other than the optimization of known processes and an adequate management of the substrates, as brewers' spent grains are generated in bulk quantities and can easily deteriorate [47]. However, others such as trub and slurries can pose a problem as when treating they by themselves. Their potential as biogas production raw materials is high but some of 
their characteristics (fluid state with a high solid load) make their treatment difficult by conventional anaerobic treatments for liquids.

Trub, furthermore, pose additional problems for their treatment as, on one hand, the cell walls of yeasts are difficult to hydrolyze [48]; and on the other, the high content in nitrogen in yeast remains may induce process inhibition due to ammonia toxicity. Besides, the antibacterial properties of compounds found in hop and which can be found in a concentrated form in trub is another factor that can hamper the anaerobic process of this substrate, so its methanogenic potential can be masked.

The researchers have collected some data on site, in a well-established artisan brewery of the region, in order to assess the waste production related to the general production of the industry. In the year 2016 they had a total production of $280,000 \mathrm{~L}$ of beer made in 110 batches (averaging $2545 \mathrm{~L}$ per batch). The good sales of the production leading to an increased demand set a horizon for the year 2019 of an increased production of up to 150 batches. For each batch, an amount of $500 \mathrm{~kg}$ of dry malt and $15 \mathrm{~kg}$ of hops are used, which transforms roughly into $750 \mathrm{~kg}$ of wet spent brewer's grains. Fermentation of the wort is initiated by the inoculation or pinching of $2 \mathrm{~kg}$ of yeast per batch, which become $100 \mathrm{~L}$ of trub at the end of the process. The amount of water used for cleansing purposes of the equipment is reduced by keeping the process as aseptic as possible and just using a limited amount of water mixed with caustic lye to create a very alkaline cleansing solution, so no more than $18,250 \mathrm{~L}$ of solution are used per year. The final amount of brewer's spent grains for this brewery was of $82,500 \mathrm{~kg}$ per year in 2016, which would be increased up to $112,500 \mathrm{~kg}$ in 2019. The disposal method used by the brewery is to give the wastes for free to farms, so they can be used to feed livestock. The other breweries in the region do not reach the amount of production of the one studied, with modest figures in term of both sales and waste production.

The brewing process takes place throughout the whole year and so does the generation of wastes. However, artisan breweries are scattered along the region, most of them being small sized (microbreweries). This poses a difficulty for joint waste management in the shape of cooperatives and the consequential benefit of scale economy profit. The fact that a number of them are placed in rural areas with farms and agricultural exploitations, however, could provide opportunities for biogas generation of these brewery wastes as co-substrates in addition to other farm production wastes whose potential as substrates for biogas production has been proven [49].

About wine production, even though there are no data available about waste production, they could be extrapolated from data attained through the vineyard surveys performed by the Ministerio de Agricultura, Pesca y Alimentación del Gobierno de España [50,51] and the production data of wines with protected geographical indication (IGP) [52] of the Spanish Ministry of Agriculture (MAPAMA). There are two geographical indications in Cantabria under which the great majority of wine produced in the region are compliant-Liébana wines and wines from the coast of Cantabria. Almost the totality of grape marc of Liébana wines is used to make orujo and the data about this exhausted grape marc is treated separately in this work, so this part of the work will be focused in the coast of Cantabria wine production.

The surface of vineyards in the coast of Cantabria IGP, which was of 32 hectares in 2009, had increased to 52 hectares in 2017 and, with an increase of wine production from $440 \mathrm{hL}$ in 2009 to $812 \mathrm{hL}$ in 2017 and 1074 in 2018. This obvious increased trend is reinforced taking in account that the vineyard surveys for Cantabria showed a surface of 50 hectares in 2009 (with Liébana and the coast joined, which is consistent with the IGP data for that same year giving 15 and 32 hectares respectively to each IGP, so the state of the remaining 3 hectares could be supposed as not in production), which had become 122.35 hectares in 2015. As the IGP data for 2017 were of 52 and 19 hectares for the coast and Liébana regions respectively, there's a difference of 51.35 hectares, which could be attributed to new planted vineyards, not in production yet but which will add in a near future in terms of production both of wine and its wastes.

As the specifications for the IGP are that the maximum yield attained through grape pressing is that of $70 \mathrm{~L}$ of wine for each $100 \mathrm{~kg}$ of grapes used, it could be concluded that the production of wastes 
in the shape of grape marc for the years 2009 and 2017 was of 189 and 348 tons respectively. These figures will increase significantly when the new planted vineyards start production.

As it happens with orujo, waste production has a characteristic of seasonality, being produced at certain times of the year associated to the processes of winemaking. The geographical location of the wineries associated to the IGP is varied and spread throughout the region but among the different locations, there is a strong nucleus in wine production in the neighboring municipalities placed by the eastern coast: Valle de Villaverde, Liendo, Barcena de Cicero and Voto. There are two other lesser production nuclei in some municipalities around the valleys of the river Pas, with municipalities such as Villafufre and Castillo Pedroso and the Besaya-Saja zone with the close municipalities of Cieza and Mazcuerras.

\subsection{Practical Application of the Results of the BMP Tests}

The methane yield for the accumulated amounts of different by-products varies with their nature. For exhausted grape marc, we could give a figure of 6842 cubic meters of biomethane per year just taking into account the material used for orujo under the IGP label, which increases to 9003 cubic meters adding up the waste from the distillation of marcs originating from other zones than Liébana. While these figures are modest, it must be considered that other wastes associated to wine and orujo production could be added to the process (like grape stalks from destemming, whose methanogenic potential in the fork of $98 \mathrm{~L}_{\mathrm{N}} \mathrm{CH}_{4} \mathrm{~kg} \mathrm{VS}^{-1}$ [33] to $140.25 \mathrm{~L}_{\mathrm{N}} \mathrm{CH}_{4} \mathrm{~kg} \mathrm{VS}^{-1}$ [35] could supplement and add to that obtained from grape marc; or vine trimmings) which could increase the total methane yield.

From wine production in the coastal region, the potential biomethane production which was of 17,025 cubic meters in 2009 and had increased up to 31,348 in 2017, could be an interesting way of waste management and resource exploitation, bearing in mind that a significant number of hectares of vineyards have been planted but are not yet in production. When this happens, the biomethane yield could increase up to double the current figures. It should be also taken in account that, in the previous figures, grape stalks, vine trimmings or wine lees (withmethanogenic potentials ranging from $370 \mathrm{~L}_{\mathrm{N}}$ $\mathrm{CH}_{4} \mathrm{~kg} \mathrm{VS}^{-1}$ according to Da Ros et al. [36] to $513 \mathrm{~L}_{\mathrm{N}} \mathrm{CH}_{4} \mathrm{~kg} \mathrm{VS}^{-1}$ according to Jasko et al. [53] and amounting to between $2 \%$ and $6 \%$ of the total wine production according to Spigno et al. [54]) have been kept out as material susceptible to undergo anaerobic treatment. Generally speaking, the potential energy content of the residual biomass produced from a hectare of grapevine has been evaluated in about 19 GJ of gross energy [55].

About brewer's grains, the geographical dispersion of breweries and their scarce volume of production make anaerobic treatment of the by-products and wastes impractical in most cases. On the other hand, the fact that a number of these microbreweries are placed in rural areas where other co-substrates suited for anaerobic treatment are readily available, could increase the feasibility of the implementation of anaerobic treatment systems which could be used in these cases [56]. No data about final products and waste generation of all breweries in Cantabria are available. There is only one case on which the evolution of production and subsequent wastes have increased a potential biomethane yield from 6438 cubic meters in 2016 to 8800 in 2019 from brewer's grains only (excluding trub and other wastes). This makes anaerobic treatment a prospective interesting option for self-consumption for the brewing processes in the company facilities. The added potential biomethane production of the rest of the breweries in the region could be estimated in an amount equal to the one of the aforementioned brewery, as could be concluded by adding up the fragmentary and scattered information about beer production of the companies obtained by different sources.

Pot ale, gin spent wash and solid aromatics waste from gin production are wastes that have appeared either as the result of traditional orujo distilleries diversification of their production or as the consequence of the appearance of new distilleries in the region, producing spirits other than those traditional in local production. As these are by-products originating from the appearance of new lines of production in a development phase and not yet consolidated, their volume is unknown and their importance in the total potential biogas production is yet to be assessed. Nevertheless, if 
those production lines becomes firmly established, they could add to the potential biogas production of exhausted grape marc, complementing it and providing a non-seasonal source of substrate for biogas production.

Using only brewers' spent grains and grape marc, both from wine production and exhausted from orujo distillation, the produced energy and $\mathrm{CO}_{2}$ reduction potential for these wastes can be calculated following the methodology in Özer (using an electricity conversion efficiency factor, $\eta=40 \%$ ) [57]. Other wastes and by-products have not been evaluated due to the difficulties in their production assessment. The results are:

Total methane potential: TMP $=57,951 \mathrm{~m}^{3} \mathrm{CH} 4 /$ year

Amount of possible electricity generation from methane: $\mathrm{e}_{\mathrm{bio}}=231,804 \mathrm{kWh} / \mathrm{year}$

Emission reduction from electricity generation: $\mathrm{ER}_{\mathrm{el}}=516,993 \mathrm{~kg} \mathrm{CO}_{2} /$ year

Total emission reduction: TER $=1,476,578 \mathrm{~kg} \mathrm{CO}_{2} /$ year

As a final note, the adoption and development of anaerobic treatment solutions should consider several factors for their successful implementation. Ideally, the technologies should require installations of a limited size [58] as the premises of the industries are usually small. This would also be influential on the economic aspects of the process.

Another question that must be taken into account is that of the possible benefits of other agri-food industries in the region, making new possibilities available for treatment of their wastes. Fish preserving is another important industrial field in the region, with a number of small factories gathered in locations not far from some beverage production areas (as the municipalities of Santoña and Castro Urdiales, very close or included in the wine-making areas of the "Costa de Cantabria") as well as a number of small cheese factories scattered by the region (normally with no management plans for whey and other by-products). Even if specific waste management plans are generally out of the reach of these small factories, their wastes could add to the substrates used for biogas production. Further research should be necessary about the feasibility of the biological processes with such co-substrates due to their peculiarities (high content of protein and/or some other elements as sodium).

The economic feasibility of anaerobic digestion technologies could depend on the capability of the industries to join forces and create consortiums, among industries of the same alcoholic beverage production field or adding other agri-food industries or agricultural exploitations to benefit from scale economy advantages in order to afford installations of an adequate size, which could have a centralized management and operation, reducing costs and payback time (ideally 15 years or less) for the needed investments [59-61].

\section{Conclusions}

The growing importance of the alcoholic beverage production industry in the region of Cantabria has brought an associated production of specific wastes, which need to be treated according to their nature. Anaerobic treatment can be a useful tool for their treatment, especially for those whose production takes place in specific areas within a limited geographic range. This way, not only a good way of specific treatment for the new flood of wastes would be implemented but also a source of power in the shape of biogas would be available for an industrial sector with an important demand of energy (mainly in the shape of heat) making it more self-sustainable both in terms of economy and environmental impact. The relatively low waste production at the current stages of the industry can be overcome by communal or cooperative treatment of wastes or by-products from industries located in geographical proximity. The facts that most facilities are placed in rural areas, where other co-substrates can be easily found and used for co-digestion and digestate can find an easy outlet as a fertilizer or soil amendment is another advantage to be taken in account.

Author Contributions: Conceptualization, C.R.; methodology, C.R.; data curation, J.A.M. and C.R.; writing—original draft preparation, J.A.M.; writing-review and editing, J.A.M.; supervision, C.R. All authors have read and agreed to the published version of the manuscript. 
Funding: This research received no external funding.

Acknowledgments: The authors want to thank the management and staff of Destilería Siderit S.L., Cervezas Artesanales de Cantabria S.L. (Dougall's) and Orujo de Liébana S.A. for their support, providing information and samples of wastes and by-products used in this article.

Conflicts of Interest: The authors declare that they have no known competing financial interests or personal relationships that could have appeared to influence the work reported in this paper.

\section{Nomenclature}

\begin{tabular}{|c|c|}
\hline $\mathrm{AD}$ & Short for anaerobic digestion. \\
\hline BMP & Short for biochemical methanogenic potential. \\
\hline COD & Short for chemical oxygen demand. \\
\hline $\mathrm{e}_{\text {bio }}$ & Amount of possible electricity generation from biomethane. Expressed in kWh/year. \\
\hline $\mathrm{ER}_{\mathrm{el}}$ & Emission reduction from electricity generation (using biomethane). Expressed in $\mathrm{kg} \mathrm{CO}_{2} /$ year. \\
\hline GDP & Short for gross domestic product. \\
\hline $\mathrm{L}_{\mathrm{N}} \mathrm{CH}_{4} \mathrm{~kg} \mathrm{VS}^{-1}$ & $\begin{array}{l}\text { Liters of methane in standard conditions per kilogram of volatile solids in the feedstock. Out } \\
\text { of convenience and as usual in literature, it is the unit of choice to express methane yield. } \\
\text { To translate into SI units }\left(\mathrm{m}^{3}{ }_{\mathrm{N}} \mathrm{CH}_{4} \mathrm{~kg} \mathrm{VS}^{-1}\right) \text {, the values should be multiplied by } 10^{-3} \text {. }\end{array}$ \\
\hline$\eta$ & Electricity conversion efficiency factor. \\
\hline PAC & Short for powdered activated charcoal. \\
\hline TAN & $\begin{array}{l}\text { Short for total ammonia nitrogen. Out of convenience and as usual in literature, it is expressed } \\
\text { in } \mathrm{g} \mathrm{NH}_{4}^{+}-\mathrm{N}^{-1} \text {. }\end{array}$ \\
\hline TER & Total emission reduction (using biomethane). Expressed in $\mathrm{kg} \mathrm{CO}_{2} /$ year. \\
\hline TMP & Short for total methane potential. \\
\hline TS & Short for total solids. Expressed as a percentage of the mass of a solution. \\
\hline TKN & $\begin{array}{l}\text { Total Kjeldahl nitrogen. Out of convenience and as usual in literature, it is expressed in } \mathrm{g} / \mathrm{kg} \\
\text { TS. To translate into SI units ( } \mathrm{kg} / \mathrm{kg} \text { TS), the values should be multiplied by } 10^{-3} \text {. }\end{array}$ \\
\hline VFA & Short for volatile fatty acids. \\
\hline VS & $\begin{array}{l}\text { Volatile solids. Expressed as a percentage, either of the mass of a solution (as in this work) or } \\
\text { of the total solids in the solution. }\end{array}$ \\
\hline
\end{tabular}

\section{References}

1. ICANE InstitutoCántabro de Estadística. Available online: https://www.icane.es/ (accessed on 12 April 2020).

2. INE Instituto Nacional de Estadística. EncuestaSobreGeneración de Residues en el Sector Industrial. Serie 2012-2016. Available online: https://www.ine.es/dynt3/inebase/es/index.htm?type=pcaxis\&path=/t26/e068/ p02/serie\&file=pcaxis (accessed on 12 April 2020).

3. Springer, N.P.; Schmitt, J. The price of byproducts: Distinguishing co-products from waste using the rectangular choice-of-technologies model. Resour. Conserv. Recycl. 2018, 138, 231-237. [CrossRef]

4. Laso, J.; Margallo, M.; García-Herrero, I.; Fullana, P.; Bala, A.; Gazulla, C.; Polettini, A.; Kahhat, R.; Vázquez-Rowe, I.; Irabien, A.; et al. Combined application of Life Cycle Assessment and linear programming to evaluate food waste-to-food strategies: Seeking for answers in the nexus approach. Waste Manage. 2018, 80, 186-197. [CrossRef] [PubMed]

5. Banias, G.; Achillas, C.; Vlachokostas, C.; Moussiopoulos, N.; Stefanou, M. Environmental impacts in the life cycle of olive oil: A literature review. J. Sci. Food Agric. 2017, 97, 1686-1697. [CrossRef] [PubMed]

6. Teigiserova, D.A.; Hamelin, L.; Thomsen, M. Review of high-value food waste and food residues biorefineries with focus on unavoidable wastes from processing. Resour. Conserv. Recycl. 2019, 149, 413-426. [CrossRef]

7. Sharma, P.; Gaur, V.K.; Kim, S.-H.; Pandey, A. Microbial strategies for bio-transforming food waste into resources. Bioresour. Technol. 2020, 299, 122580. [CrossRef] [PubMed]

8. Mussatto, S.I.; Moncada, J.; Roberto, I.C.; Cardona, C.A. Techno-economic analysis for brewer's spent grains use on a biorefinery concept: The Brazilian case. Bioresour. Technol. 2013, 148, 302-310. [CrossRef] [PubMed]

9. Garcia-Garcia, G.; Rahimifard, S. Life-cycle environmental impacts of barley straw valorisation. Resour. Conserv. Recycl. 2019, 149, 1-11. [CrossRef]

10. Rico, C.; Montes, J.A.; Lobo, A. Dry batch anaerobic digestion of food waste in a box-type reactor system: Inoculum preparation and reactor performance. J. Clean Prod. 2020, 251, 119751. [CrossRef] 
11. De Palomares, J.I.S.; de Galarreta Gómez, J.I.R.; Azpitarte, E.R.; Díaz, E.M. La Viden Cantabria: Prospección y Caracterización de VariedadesAutóctonas; Muriedas: Centro de Investigación y FormaciónAgrarias (CIFA): Muriedas, Spain, 2005; 178p, ISBN 84-689-3884-X.

12. Ruescas, J.T. El Trujal: Historia, Leyendas y NotasSobre la Manzana y la Sidra en Cantabria, 1st ed.; Torrelavega: Cantabria Tradicional, Torrelavega, Spain, 2007; 212p, ISBN 978-8496042469.

13. Iñigo, P.P. Historia de las Cervecerías Españolas Raíces de Cervezas de Santander, SA y Unión cervecera, SA (1a parte). Cerveza y Malta 2002, 156, 65-76.

14. EUR-LEX, Official Website of European Union Law. Available online: https://eur-lex.europa.eu/legal-content/ EN/TXT/?qid=1556781080548\&uri=CELEX:32008R0110 (accessed on 12 April 2020).

15. BOC. BoletínOficial de Cantabria. Official Gazette of the Autonomous Community of Cantabria. Available online: https://boc.cantabria.es/boces/verAnuncioAction.do?idAnuBlob=186396 (accessed on 12 April 2020).

16. Olajire, A.A. The brewing industry and environmental challenges. J. CleanProd. 2020, 256, 102817. [CrossRef]

17. Montalvo, S.; Martinez, J.; Castillo, A.; Huiliñir, C.; Borja, R.; García, V.; Salazar, R. Sustainable energy for a winery through biogas production and its utilization: A Chilean case study. Sustain. Energy Technol. Assess. 2020, 37, 100640. [CrossRef]

18. Bocci, E.; Di Carlo, A.; McPhail, J.; Gallucci, K.; Foscolo, P.U.; Moneti, M.; Villarini, M.; Carlini, M. Biomass to fuel cells state of the art: A review of the most innovative technology solutions. Int. J. Hydrog. Energy 2014, 39, 21876-21895. [CrossRef]

19. Papurello, D.; Silvestri, S.; Lanzini, A. Biogas cleaning: Trace compounds removal with model validation. Sep. Purif. Technol. 2019, 210, 80-92. [CrossRef]

20. Papurello, D.; Chiodo, V.; Maisano, S.; Lanzini, A.; Santarelli, M. Catalytic stability of a Ni-Catalyst towards biogas reforming in the presence of deactivating trace compounds. Renew. Energy 2018, 127, 481-494. [CrossRef]

21. Martinez, S.; Michaux, G.; Salagnac, P.; Bouvier, J.L. Micro-combined heat and power systems (micro-CHP) based on renewable energy sources. Energy Conv. Manag. 2017, 254, 262-285. [CrossRef]

22. García, N.H.; Mattioli, A.; Gil, A.; Frison, N.; Battista, F.; Bolzonella, D. Evaluation of the methane potential of different agricultural and food processing substrates for improved biogas production in rural areas. Renew. Sustain. Energ. Rev. 2019, 112, 1-10. [CrossRef]

23. Filho, M.G.; Lumi, M.; Hasan, C.; Marder, M.C.S.; Leite, L.; Konrad, O. Energy recovery from wine sector wastes: A study about the biogas generation potential in a vineyard from Rio Grande do Sul, Brazil. Sustain. Energy Technol. Assess. 2018, 29, 44-49. [CrossRef]

24. Ferreira-Leitão, V.S.; Cammarota, M.C.; Aguieiras, E.C.G.; de Sá, L.R.V.; Fernandez-Lafuente, R.; Freire, D.M.G. The Protagonism of Biocatalysis in Green Chemistry and Its Environmental Benefits. Catalysts 2017, 7, 9. [CrossRef]

25. Rajagopal, R.; Saadi, N.M.C.; Torrijos, M.; Thanikal, J.V.; Hung, Y.T. Sustainable Agro-Food Industrial Wastewater Treatment Using High Rate Anaerobic Process. Water 2013, 5, 292-311. [CrossRef]

26. Valero, D.; Alzate-Gaviria, L.; Montes, J.A.; Rico, C. Influence of a Conductive Material and Different Anaerobic Inocula on Biochemical Methane Potential of Substrates from Alcoholic Beverage Production. Waste Biomass Valorization 2020, 11, 5957-5964. [CrossRef]

27. Valero, D.; Montes, J.A.; Rico, J.L.; Rico, C. Influence of headspace pressure on methane production in Biochemical Methane Potential (BMP) tests. Waste Manage. 2016, 48, 193-198. [CrossRef] [PubMed]

28. Muhlack, R.A.; Potumarthi, R.; Jeffery, D.W. Sustainable wineries through waste valorisation: A review of grape marc utilisation for value-added products. Waste Manage. 2018, 72, 99-118. [CrossRef] [PubMed]

29. Barrena, R.; Traub, J.E.; Gil, C.R.; Goodwin, J.A.S.; Harper, A.J.; Willoughby, N.A.; Sánchez, A.; Aspray, T.J. Batch anaerobic digestion of deproteinated malt whisky pot ale using different source inocula. Waste Manag. 2018, 71, 675-682. [CrossRef] [PubMed]

30. Vitanza, R.; Cortesi, A.; Gallo, V.; Colussi, I.; De Arana-Sarabia, M.E. Biovalorization of brewery waste by applying anaerobic digestion. Chem. Biochem. Eng. Q. 2016, 30, 351-357. [CrossRef]

31. Bochmann, G.; Drosg, B.; Fuchs, W. Anaerobic digestion of thermal pretreated brewers' spent grains. Environ. Prog. Sustain. Energy 2015, 34, 1092-1096. [CrossRef]

32. Oliveira, J.V.; Alves, M.M.; Costa, J.C. Biochemical methane potential of brewery by-products. Clean Technol. Environ. Policy 2018, 20, 435-440. [CrossRef] 
33. Dinuccio, E.; Balsari, P.; Gioelli, F.; Menardo, S. Evaluation of the biogas productivity potential of some Italian agro-industrial biomasses. Bioresour. Technol. 2010, 101, 3780-3783. [CrossRef]

34. Hungría, J.; Siles, J.A.; Gil, A.; Gutiérrez, M.C.; Martín, M.A. Revalorization of grape marc waste from liqueur wine: Biomethanization. J. Chem. Technol. Biotechnol. 2019, 94, 1499-1508. [CrossRef]

35. Fabbri, A.; Bonifazi, G.; Serranti, S. Micro-scale energy valorization of grape marcs in winery production plants. Waste Manag. 2015, 36, 156-165. [CrossRef]

36. Da Ros, C.; Cavinato, C.; Bolzonella, D.; Pavan, P. Renewable energy from thermophilic anaerobic digestion of winery residue: Preliminary evidence from batch and continuous lab-scale trials. Biomass Bioenerg. 2016, 91, 150-159. [CrossRef]

37. Montes, J.A.; Leivas, R.; Martínez-Prieto, D.; Rico, C. Biogas production from the liquid waste of distilled gin production: Optimization of UASB reactor performance with increasing organic loading rate for co-digestion with swine wastewater. Bioresour. Technol. 2019, 274, 43-47. [CrossRef] [PubMed]

38. Feiz, R.; Ammenberg, J. Assessment of feedstocks for biogas production, part I-A multi-criteria approach. Resour. Conserv. Recycl. 2017, 122, 373-387. [CrossRef]

39. Ammenberg, J.; Feiz, R. Assessment of feedstocks for biogas production, part II-Results for strategic decision making. Resour. Conserv. Recycl. 2017, 122, 388-404. [CrossRef]

40. Vlachokostas, C.; Achillas, C.; Agnantiaris, I.; Michailidou, A.V.; Pallas, C.; Feleki, E.; Moussiopoulos, N. Decision support system to implement units of alternative biowaste treatment for producing bioenergy and boosting local bioeconomy. Energies 2020, 13, 2306. [CrossRef]

41. Failla, S.; Restuccia, A. Methane potentials from grape marc by a laboratory scale plant. Appl. Math. Sci. 2014, 8, 6665-6678. [CrossRef]

42. Oliveira, M.; Duarte, E. Integrated approach to winery waste: Waste generation and data consolidation. Front. Env. Sci. Eng. 2016, 10, 168-176. [CrossRef]

43. Devesa-Rey, R.; Vecino, X.; Varela-Alende, J.L.; Barral, M.T.; Cruz, J.M.; Moldes, A.B. Valorization of winery waste vs. the costs of not recycling. Waste Manage. 2011, 31, 2327-2335. [CrossRef]

44. ODECA. Oficina de CalidadAlimentaria. Gobierno de Cantabria. Available online: https://www.alimentosde cantabria.com/inicio (accessed on 12 April 2020).

45. Lorenz, H.; Fischer, P.; Schumacher, B.; Adler, P. Current EU-27 technical potential of organic waste streams for biogas and energy production. Waste Manage. 2013, 33, 2434-2448. [CrossRef] [PubMed]

46. Muster-Slawitsch, B.; Weiss, W.; Schnitzer, H.; Brunner, C. The green brewery concept-Energy efficiency and the use of renewable energy sources in breweries. Appl. Therm. Eng. 2011, 31, 2123-2134. [CrossRef]

47. Johnson, P.; Paliwal, J.; Cenkowski, S. Issues with utilisation of brewers' spent grain. Stewart Postharvest Rev. 2010, 6, 1-8. [CrossRef]

48. Mallick, P.; Akunna, J.C.; Walker, G.M. Anaerobic digestion of distillery spent wash: Influence of enzymatic pre-treatment of intact yeast cells. Bioresour. Technol. 2010, 101, 1681-1685. [CrossRef]

49. Rico, C.; Rico, J.L.; Tejero, I.; Muñoz, N.; Gómez, B. Anaerobic digestion of the liquid fraction of dairy manure in pilot plant for biogas production: Residual methane yield of digestate. Waste Manag. 2011, 31, 2167-2173. [CrossRef]

50. Ministerio de Agricultura, Pesca y Alimentación. Gobierno de España. Encuestas de Viñedo. Available online: https:/www.mapa.gob.es/es/estadistica/temas/estadisticas-agrarias/agricultura/encuestas-de-vinedo/ (accessed on 12 April 2020).

51. Ministerio de Agricultura, Pesca y Alimentación. Gobierno de España. Superficies y ProduccionesAnuales de Cultivos-DatosAvances de ViñedoAño. 2017. Available online: https://www.mapa.gob.es/es/estadistica/temas/ estadisticas-agrarias/agricultura/superficies-producciones-anuales-cultivos/ (accessed on 12 April 2020).

52. Ministerio de Agricultura, Pesca y Alimentación. Gobierno de España. Datos Denominaciones de Origen e Indicaciones Geográficas Protegidas. Available online: https:/www.mapa.gob.es/es/alimentacion/temas/ calidad-agroalimentaria/calidad-diferenciada/dop/htm/cifrasydatos.aspx (accessed on 12 April 2020).

53. Jasko, J.; Skripsts, E.; Dubrovskis, V. Biogas production of winemaking waste in anaerobic fermentation process. In Proceedings of the 11th International Scientific Conference Engineering For Rural Development, Jelgava, Latvia, 24-25 May 2012; pp. 576-579.

54. Spigno, G.; Marinoni, L.; Garrido, G.D. State of the Art in Grape Processing ByProducts. In Handbook of Grape Processing By-Products: Sustainable Solutions; Galanakis, C.M., Ed.; Academic Press: San Diego, CA, USA, 2017; pp. 1-27. ISBN 9780128098707. 
55. Toscano, G.; Riva, G.; Duca, D.; Pedrretti, E.F.; Corinaldesi, F.; Rossini, G. Analysis of the characteristics of the residues of the wine production chain finalized to their industrial and energy recovery. Biomass Bioenerg. 2013, 55, 260-267. [CrossRef]

56. Sturm, B.; Butcher, M.; Wang, Y.; Huang, Y.; Roskilly, T. The feasibility of the sustainable energy supply from bio wastes for a small scale brewery-A case study. Appl. Therm. Eng. 2012, 39, 45-52. [CrossRef]

57. Özer, B. Biogas energy opportunity of Ardahan city of Turkey. Energy 2017, 139, 1144-1152. [CrossRef]

58. Skornia, K.; Safferman, S.I.; Rodriguez-Gonzalez, L.; Ergas, S.J. Treatment of winery wastewater using bench-scale columns simulating vertical flow constructed wetlands with adsorption media. Appl. Sci.-Basel 2020, 10, 1063. [CrossRef]

59. Ali, M.Y.; Hassan, M.; Rahman, M.A.; Al Kafy, A.; Ara, I.; Javed, A.; Rahman, M.R. Life cycle energy and cost analysis of small scale biogás plant and solar PV system in rural areas of Bangladesh. Energy Procedia 2019, 160, 277-284. [CrossRef]

60. Menind, A.; Olt, J. Biogas plant investment analysis, cost benefit and main factors. In Proceedings of the 8th International Scientific Conference Engineering For Rural Development, Jelgava, Latvia, 28-29 May 2009; pp. 339-343.

61. Achinas, S.; Euverink, G.J.W. Feasibility study of biogas production from hardly degradable material in co-inoculated bioreactor. Energies 2019, 12, 1040. [CrossRef]

Publisher's Note: MDPI stays neutral with regard to jurisdictional claims in published maps and institutional affiliations. 